\title{
Pharmacognosy
}

\section{Investigation of wound healing activity of Lafoensia pacari (Lythraceae) leaves extract cultivated in Goiás state, Brazil}

\author{
Beatriz Abdallah Chaibub ${ }^{1}$, Leila Maria Leal Parente ${ }^{1}$, Ruy de Souza Lino $\mathrm{Jr}^{2}$, \\ Herica Nubia Cardoso Cirilo ${ }^{1}$, Sandra Alves de Sousa Garcia ${ }^{1}$, João Carlos Mohn Nogueira ${ }^{3}$, \\ Edemilson Cardodo da Conceição ${ }^{1}$, Douglas Vieira Thomaz ${ }^{1}$, Suzana da Costa Santos ${ }^{4}$ \\ \& Maria Teresa Freitas Bara ${ }^{1,5,6}$
}

\begin{abstract}
Lafoensia pacari has been used in traditional folk medicine in Brazilian Cerrado to treat wounds. It is important to develop studies that can clarify how the biological activity of $L$. pacari occurs. The aim of this study was to evaluate the healing activity of $L$. pacari leaves extract in an animal model. The extract was prepared from plants cultivated in Goiania-GO, Brazil. The healing activity was assayed using cutaneous wound model in rats, and macroscopic, morphometric and histological analysis of wounds were also conducted. The presence of hydrolysable tannins was detected in thin layer chromatography and in high performance liquid chromatography analysis, may be suggested the presence of ellagitannins. In the evaluation of cutaneous wounds in rats it was possible to observe that the treatment with $10 \%(\mathrm{w} / \mathrm{v})$ L. pacari extract provided a reduction in the time of cutaneous wound healing, with a significant increase in variables involved in healing, such as the number of blood vessels and collagen production. Therefore, this study shows that $L$. pacari wound healing potential may be related to the presence of ellagitannins and corroborates to ethnopharmacological reports regarding this plant.
\end{abstract}

Key words: bioactivity, Cerrado, medicinal plant, tannin.

\section{Resumo}

Lafoensia pacari é empregada na medicina tradicional no cerrado Brasileiro para tratar feridas. É importante desenvolver estudos para melhor compreender como ocorre a atividade biológica de $L$. pacari . O objetivo deste estudo foi avaliar a atividade cicatrizante do extrato das folhas de L. pacari em modelo animal. O extrato vegetal foi preparado a partir de plantas oriundas de Goiânia-GO, Brasil. Na avaliação da atividade cicatrizante, foi empregado o modelo de feridas cutâneas em ratos. Análise macroscópica, morfométrica e histológica das feridas também foram realizadas. Na cromatografia de camada delgada foi detectada a presença de taninos hidrolisáveis e na cromatografia líquida de alta eficiência, pôde-se sugerir a presença de elagitaninos. Na avaliação das feridas cutâneas em ratos foi possível observar que o tratamento com extrato de $L$. pacari a $10 \%(\mathrm{~m} / \mathrm{v})$ proporcionou uma redução no tempo de cicatrização de feridas cutâneas em ratos, com aumento significativo das variáveis envolvidas na cicatrização, como número de vasos sanguíneos e a produção de colágeno. Portanto, este estudo mostra que o potencial cicatrizante de L. pacari pode estar relacionado à presença de elagitaninos, o que corrobora com relatos etnofarmacológicos deste vegetal.

Palavras-chave: bioatividade, Cerrado, planta medicinal, tanino.

\footnotetext{
${ }^{1}$ Universidade Federal de Goiás, Faculdade de Farmácia, C.P. 131, 74605-170, Goiânia, GO, Brasil.

${ }^{2}$ Universidade Federal de Goiás, Inst. Patologia Tropical e Saúde Pública, C.P. 131, 74605-050, Goiânia, GO, Brasil.

${ }^{3}$ Agência Goiana de Assistência Técnica, Extensão Rural e Pesquisa Agropecuária (Emater), Rod. AR-2, Qd. E, Lt. AR-3, Campus 2 da UFG, 74690-815, Goiânia, GO, Brasil.

${ }^{4}$ Universidade Federal de Goiás, Inst. Química, C.P. 131, 74001-970, Goiânia, GO, Brasil.

${ }^{5}$ ORCID: < https://orcid.org/0000-0003-4942-8721>

${ }^{6}$ Author for correspondence: mbara@ufg.br, mtbara@gmail.com
} 


\section{Introduction}

Cerrado is the second biggest Brazilian biome, whose area comprises more than $25 \%$ of the country area. It represents $33 \%$ of national and $5 \%$ of global biodiversity (Santos et al. 2010; Brazil 2013) and $44 \%$ of its flora is endemic (Klink \& Machado 2005). Despite the richness of flora and fauna species, the Brazilian Cerrado is target of devastation and extinction due to agricultural, livestock and extractivism expansion. In this sense, literature reports that over $50 \%$ of this biome was devastated (Brazil 2011) and is considered a priority area for conservation due to the high degree of threat of extinction, a worldwide hotspot (Fachim \& Guarim 1995; Klink \& Machado 2005; Santos et al. 2010).

Among the most representative families of the Cerrado flora is Lythraceae, which comprises 22 genera distributed around the world (Joly 2002; Ribeiro \& Dias 2007). In Brazil, Lafoensia genus comprises 6 distinct species, namely Lafoensia pacari A. St.-Hil., Lafoensia densiflora Pohl, Lafoensia glyptocarpa Koehne, Lafoensia replicata Pohl, Lafoensia vandelliana Cham. \& Schltdl, Lafoensia nummularifolia A. St.-Hil. (Sano et al. 2008).

Lafoensia pacari is a species widely used by the Cerrado population, being highlighted in the Cerrado Pharmacopoeia (Dias \& Laureano 2009), also has potential for landscaping and riparian forest replacement (Camillo et al. 2016). Furthermore, $L$. pacari is widely distributed in Cerrado, occurring in more than $50 \%$ of its area (Ribeiro \& Dias 2007). Regarding its morpho-anatomical features, L. pacari is a perennial to semi-deciduous tree, found in Cerrado, Cerradão, riparian forest, dry forest and high-altitude forests. Its canopy has young, reddish, square and sharp terminal branches. The trunk has a diameter of up to $26 \mathrm{~cm}$, with a grayish, scaly rhytidoma presenting sinuous and discontinuous fissures and ridges. Its height may vary from 1 to $10 \mathrm{~m}$ (Lorenzi 1998; Carvalho 2003; Camillo et al. 2016). Concerning its phenology, L. pacari flowering at the end of the rainy season, from April to August, fruiting occurs between June and September, with fruit dispersion being more intense in September. Moreover, its leaves fall from July to September and new leaves grow from September to December, with the beginning of the rains (Santos et al. 2009).

Lafoensia pacari is regionally known as "pacari", "mangava-brava", "dedal" or "dedaleiro" (Lorenzi 1998) and also as "amarelinho", "candeiade-caju", "pau-tinta", etc (Camillo et al. 2016).
Ethnopharmacological studies describe L. pacari as wound-healer (Vila Verde et al. 2003), being useful for treating ulcer, gastritis, healing and inflammation (Souza 2007; Cabral \& Pasa 2009; Jesus et al. 2009).

Literature reports the presence of flavonoids (Santos et al. 2000; Pereira et al. 2018) and tannins (Sampaio et al. 2011; Carneiro et al. 2016; Pereira et al. 2018) in L. pacari leaves. These polyphenols are highly relevant towards the biological activity of plants and have important medical and ecological purposes (Monteiro et al. 2005). Moreover, hydrolysable tannins such as ellagitannins have been reported to occur in Lythraceae (Yoshida et al. 2010).

The healing activity of medicinal plants has shown that these natural agents induce healing and regeneration of lost tissue by multiple mechanisms and is considered a result of the synergistic activity of different secondary metabolites, whose tannins contribute significantly (Logeeswari \& Sripathi 2012). Among the species to which wound healing properties can be attributed, there are Stryphnodendron sp. (Lopes et al. 2005; Coelho et al. 2010), Lawsonia inermis L. (Muhammad \& Muhammad 2005; Nayak et al. 2007); Schinus terebinthifolius Raddi (Castelo Branco et al. 2006); Tabernaemontana catharinensis DC. (Janning et al. 2011); Punica granatum L. (Hayouni et al. 2011; Ismail et al. 2012); Ammannia baccifera L. and Blepharis maderaspatensis (L.) B. Heyne ex Roth. (Rajasekaran et al. 2012). Regarding L. pacari, there was a single report using plants extracted in Brazilian Mato Grosso region, in which wound healing effects were detected both in vitro and in vivo (Pereira et al. 2018). In this study, the authors used a species collected from the natural environment, the extract was prepared differently from ours and the experimental model was more complex.

This work aimed to corroborate with studies on the wound healing effects of L. pacari, having as differential the use of a species cultivated in Goiania, Goiás state, Brazil, using an in vivo model comprising cutaneous wounds in rats.

\section{Materials and Methods}

Vegetal material and extract

Lafoensia pacari leaves were collected from adult trees cultivated at the Goiania Agency of Technical Assistance, Rural extension and Agropecuary Research - EMATER (16 36'19"'S, 49 $15^{\prime} 48^{\prime}$ 'W, 710 m high) in Goiânia-Goiás, Brazil, in May 2016. The vegetal material was identified by the Professor Maria Teresa Freitas Bara of the 
Federal University of Goias (UFG), according to Lorenzi (1998). A sample voucher was stored in UFG herbarium under the code UFG-47581.

Lafoensia pacari leaves were cleaned and desiccated at environment temperature. Thereafter, the leaves were milled in knifes-mill (WillyeTecnal) and extracted using acetone/water $50 \%$ with ultrasound bath for $30 \mathrm{~min}$ at $10 \%(\mathrm{w} / \mathrm{v})$ drug:solvent ratio. After extraction, the solvent was evaporated using reduced pressure at constant temperature of $35^{\circ} \mathrm{C}$. Then, the extract was filtrated and partitioned using analytical grade ethyl acetate $(10 \times 100 \mathrm{~mL})$. The hydrophilic portion was separated and subjected to lyophilization.

\section{Lafoensia pacari extract} characterization

In order to characterize L. pacari extract prior lyophilization, solids content and $\mathrm{pH}$ were determined according to the $5^{\text {th }}$ edition of Brazilian Pharmacopoeia (Brazil 2010), all assays were conducted in triplicates, and results were expressed as means of three independent experiments. The verification of the presence of hydrolysable tannins was performed using thin layer chromatography (TLC) (Mello \& Santos 2017) of the extract prior lyophilization, and high performance liquid chromatography (HPLC) (Okuda et al. 1989) of the lyophilized extract.

TLC was conducted on standard silica sheets (Merck) using $20 \mu \mathrm{L}$ sampling volume of $1 \mathrm{mg}$ extract in $1 \mathrm{~mL}$ methanol. The mobile phase consisted of acetone, toluene and formic acid at proportion of $3: 3: 1(\mathrm{v} / \mathrm{v} / \mathrm{v})$ respectively. The revelation was performed using vanilin $/ \mathrm{H}_{2} \mathrm{SO}_{4}$ solution, followed by heating or exposure to $\mathrm{FeCl}_{3} /$ $\mathrm{HCl}$ at $1 \%$.

HPLC assay was conducted at Waters chromatographer using quaternary pump, e2695 separation module, diode array detector (DAD) 2998, and Empower 2.0 data system. The stationary phase used was a Waters C 18 column of $250 \times 4.6$ $\mathrm{mm}$, injection volume of $10 \mu \mathrm{L}$ (extract at $1 \mu \mathrm{g}$ / $\mathrm{mL}$ ), operational temperature of $25^{\circ} \mathrm{C}$, maximum detection at wavelength of $254 \mathrm{~nm}$ and mobile phase flux of $1.0 \mathrm{~mL} / \mathrm{min}$. The mobile phase consisted of acetonitrile and phosphate buffer 0.01 $\mathrm{M}(\mathrm{v} / \mathrm{v})$ following a gradient of 8:92 for $20 \mathrm{~min}$, then changed to $18: 82$ proportion for $15 \mathrm{~min}$, to 50:50 for $10 \mathrm{~min}$, then $80: 20$ for $3 \mathrm{~min}$ and ended at 8:92 proportion, with the total elution time of $50 \mathrm{~min}$.
Animals

20 isogenic female Wistar rats (Rattus norvegicus albinus) were selected for this study. All rats were healthy and aged 60 days old. Moreover, they weighted between 160 to 190 g. All rats were acquired from UFG's Central Bioterium, and the experiments took place under controlled temperature of $23 \pm 2{ }^{\circ} \mathrm{C}$, humidity between 50 and $60 \%$, and night/day cycle of 12 h. Water and food were given ad libitum, and all herein described procedures were conducted according to standard animal experimental models, as described by Lopes et al. (2005) and Garros et al. (2006) This experimental protocol was developed in accordance with Brazilian Council for Controlling of Animal Experiments (CONCEA) and were approved by the Research Ethic Council of UFG (number 067/2).

\section{Wound healing study model}

All animals were weighted and randomly distributed in 4 treatment groups, each comprising 5 animals. The groups were:

C1: control group, which was treated with distilled water for 7 days;

C2: test group, treated with $L$. pacari extract at $10 \%$ in distilled water for 7 days;

C3: control group, which was treated with distilled water for 14 days;

C4: test group, treated with L. pacari extract at $10 \%$ in distilled water for 14 days.

\section{Macroscopic evaluation}

Initially, a surgical procedure was conducted to promote the cutaneous wounds to be assayed in this study. The wound were made in the epilated dorsal-cervical region and using a circular metallic punch of $1 \mathrm{~cm}$ diameter. All animals undergone the aforementioned procedures under anesthesia (ketamine $70 \mathrm{mg} / \mathrm{kg}$ and xylazine, $10 \mathrm{mg} / \mathrm{kg}$, intramuscular). Immediately after surgery and daily at the same time of each treatment, the wound area was subjected to applications of either $100 \mu \mathrm{L}$ of distilled water (C1 and $\mathrm{C} 3$ groups) or $100 \mu \mathrm{L} \mathrm{L}$. pacari extract at $10 \%$ (C2 and $\mathrm{C} 4$ groups). These applications were conducted by dripping with a sterile syringe. During the first two days following surgery, all rats received orally the analgesic tramadol chlorhydrate to minimize pain. All animals were examined daily regarding the general aspect of wounds focusing on episodes of hyperemia, hemorrhage, exudate presence and 
other inflammatory or pathologic signals. After 7 days of treatment for $\mathrm{C} 1$ and $\mathrm{C} 2$ groups, and after 14 days for $\mathrm{C} 3$ and $\mathrm{C} 4$ groups, the animals were again weighted and euthanized in $\mathrm{CO}_{2}$ chamber.

\section{Morphometric and histological analysis}

The wounds were evaluated at days zero, 7 (C1 and C2 groups) and 14 (C3 and C4 groups) using digital camera with lenses positioned at $27 \mathrm{~cm}$ from the wounds. All images were analyzed using Image J 1.3.1 software (NIH, USA). Moreover, the level of area contraction (GC) was calculated taking the original wound area in consideration according to standard protocol (Oliveira et al. 2000).

The histological evaluation was performed using a tissue fragment of the wounds removed after euthanasia of the animals, fixed in buffered formalin, blocked with paraffin, sectioned in microtome and stained with hematoxylin and eosin. At the $7^{\text {th }}$ day, the following variables were evaluated: collagen and fibrin production, hemorrhage, hyperemia and inflammatory infiltrate. At the $14^{\text {th }}$ day of treatment, re-epithelization and epidermal hyperplasia were evaluated. The images were captured using a digital camera and were analyzed using Image J 1.3.1 software (NIH, USA). The variables analyzed were counted in three fields for each processed fragment and for each treatment individual and then the medians of the histological variables evaluated were determined for the groups treated with $L$. pacari extract when compared to those treated with distilled water (control) (BiondoSimões et al. 2006) .

\section{Statistical analysis}

All results were analyzed using MannWhitney test, being statistical significance attributed to $p \leq 0.05$. Furthermore, all data was treated using GraphPad InStat 3.0 software.

\section{Results and Discussion}

Lafoensia pacari extract characterization Initially, we would like to emphasize that we obtain the vegetal matter in a sustainable way, since it was cultivated in EMATER (Goiânia-GO). This was important because the popular use of $L$. pacari has been limited due to the peculiarities of its spread during the dry season, when forest fires occur in the Cerrado. In addition, its seeds are particularly susceptible to damage that limits their propagation as they are not protected by any fruit tissue (Camillo et al. 2016). Thus, the cultivation of the species is fundamental.

After processing, L. pacari extract showed solids content of $5.44 \% \pm 0.31$ and $\mathrm{pH}$ of $4.23 \pm$ 0.02 (prior lyophilization). The acidic $\mathrm{pH}$ found on L. pacari extract may be attributed to the extraction of phenolic compounds, which is known to have acidic reaction. Regarding the drying of the extract, it was performed by lyophilization aiming to limit the degradation of thermolabile compounds, such as phenols, which may undergo oxidation (Mello \& Santos 2017).

The presence of hydrolysable tannins was showed by TLC, that was revealed using vanillin solution and there were no visible bands. However, upon revelation with iron chloride, blue bands were observed at retention factor of 0.15 . The negative results in presence of vanillin-acid solution and positive results upon application of iron chloride allows to suggest this presence (Mello \& Santos 2017).

From HPLC analysis, we can state that among the hydrolysable tannins, we have punicalagin. We highlight that in another study of our group (Carneiro et al. 2016), with this same extract and under the same analytical conditions, punicalagin had already been identified through the absorption spectrum, retention time on HPLC and by using spectroscopic methods (ESI-TOF MS, 1D and 2D NMR). So, we refer to the original article that identified it, and in the present work, we only verify this presence by HPLC analysis (retention time and absorption spectrum). HPLC results evidenced the chromatographic profile of $L$. pacari extract, wherein Figure 1a showed two major peaks at retention times of 14.68 and $17.61 \mathrm{~min}$ respectively. By analyzing their absorption spectra (Fig. 1b,c), it was possible to observe three identical maximum absorption bands visible at 214.6, 257.1 and $379.7 \mathrm{~nm}$, which were nonetheless identical to the both peaks visualized in chromatograms. L. pacari extract absorption spectra results were fairly similar to other reports in literature, being observed small variations such as 218,260 and $379 \mathrm{~nm}$ (Machado et al. 2002); 215, 257 and 375 $\mathrm{nm}$ (Asres et al. 2001); and 213, 258 and $380 \mathrm{~nm}$ (Romani et al. 2012). Furthermore, one of the major features of hydrolysable tannins is the presence of $\alpha$ or $\beta$ anomeric hydrogens, which present two peaks under HPLC analysis (Machado et al. 2002). Considering this, the results published by Doig et al. (1990) showed the structural determination of punicalagin anomers from Terminalia oblongata, 

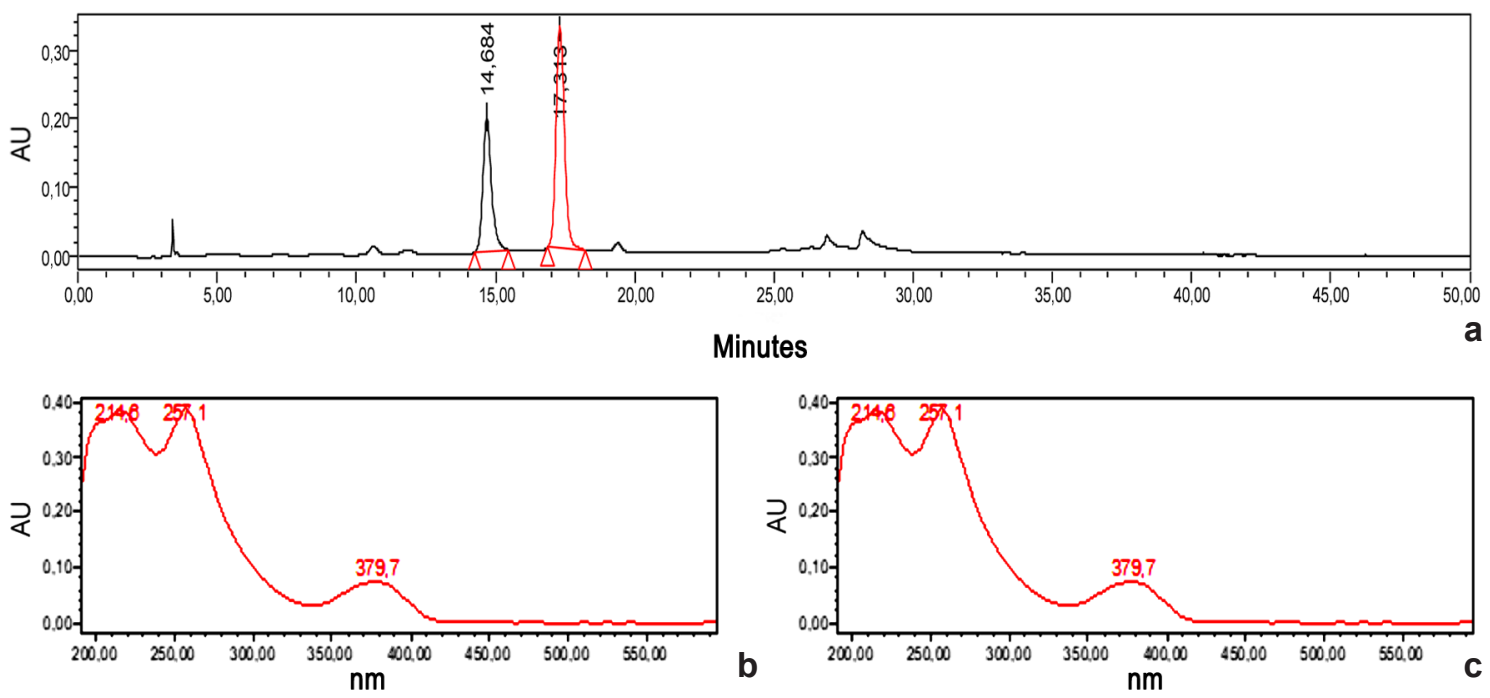

Figure 1 - a. HPLC chromatographic profile of the L. pacari extract, highlighting the two detected peaks (peak $1=$ 14.684 min and peak $2=17.313 \mathrm{~min}$ ); b. absorption spectra at $254 \mathrm{~nm}$ of peak $1 \mathrm{of} L$. pacari extract; c. absorption spectra at $254 \mathrm{~nm}$ of peak 2 of L. pacari extract.

which were extracted under similar conditions to the one analyzed in this work. Given the similar findings, we therefore suggest the presence of hydrolysable tannins such as punicalagin in $L$. pacari extract.

Regarding the extraction process herein used, we chose for $50 \%$ acetone solution followed by partition with ethyl acetate due to its reported capacity to optimize tannin extraction. In this sense, we can also imply the presence of polar compounds such as flavonoids, phenolic acids and tannin monomers (Mello \& Santos 2017), which were conserved post lyophilization and used in experimental models of wound healing.

Investigation of wound healing activity of Lafoensia pacari extract

Results showed that, in the macroscopic evaluation of the wounds treated with $L$. pacari extract was not observed sanguinolent exudate, neither was this found in control group. In the animals treated with $L$. pacari extract, thin scabs covered the wounds after the $2^{\text {th }}$ day, being thickened over time on the $3^{\text {th }}$ and $4^{\text {th }}$ day. On the $4^{\text {th }}$ day, the scabs were seemingly untied to the tissue and the wound borders started to recede. In the control group there was no visible scab until the $4^{\text {th }}$ treatment day, at which they only became loose on the $6^{\text {th }}$ day. After scabs were untied from wound tissue, both wounds reduced gradually in size and in the $14^{\text {th }}$ day, there was no visible wound and partial reconstitution of hair growth. (Fig. 2 - C1, C2, C3 and C4). Therefore, it was possible to observe that L. pacari extract at $10 \%$ aided in wound recovery time, promoting healing acceleration.

The macroscopic aspect of wound scabs seen in this work were similar to other reports regarding wound healing properties of natural products, wherein the overall aspect of the wound is marked by thick and darkened scabs (Lopes et al. 2005).

In the morphometric evaluation there was no significant difference between wound size in the $7^{\text {th }}$ and $14^{\text {th }}$ day of treatment (Fig. 2). However, there was a qualitative improvement of wound aspect and healing time in the animals treated with $L$. pacari extract at $10 \%$.

The histologic evaluation of $L$. pacari extract-treated wound tissue evidenced that, at the $7^{\text {th }}$ day, there was a significant increase in collagen production, as well as neoangiogenesis when compared to control group (Tab. 1; Figs. $3 ; 4)$. The other analyzed parameters, such as fibrin production, as well as hyperemia, hemorrhage and inflammatory infiltrate did not showed statistically significant differences.

The histologic analysis of wound tissue removed on the $14^{\text {th }}$ day evidenced total reepithelization in the wound area of all animals. There was moreover no significative difference regarding epidermal hyperplasia. 

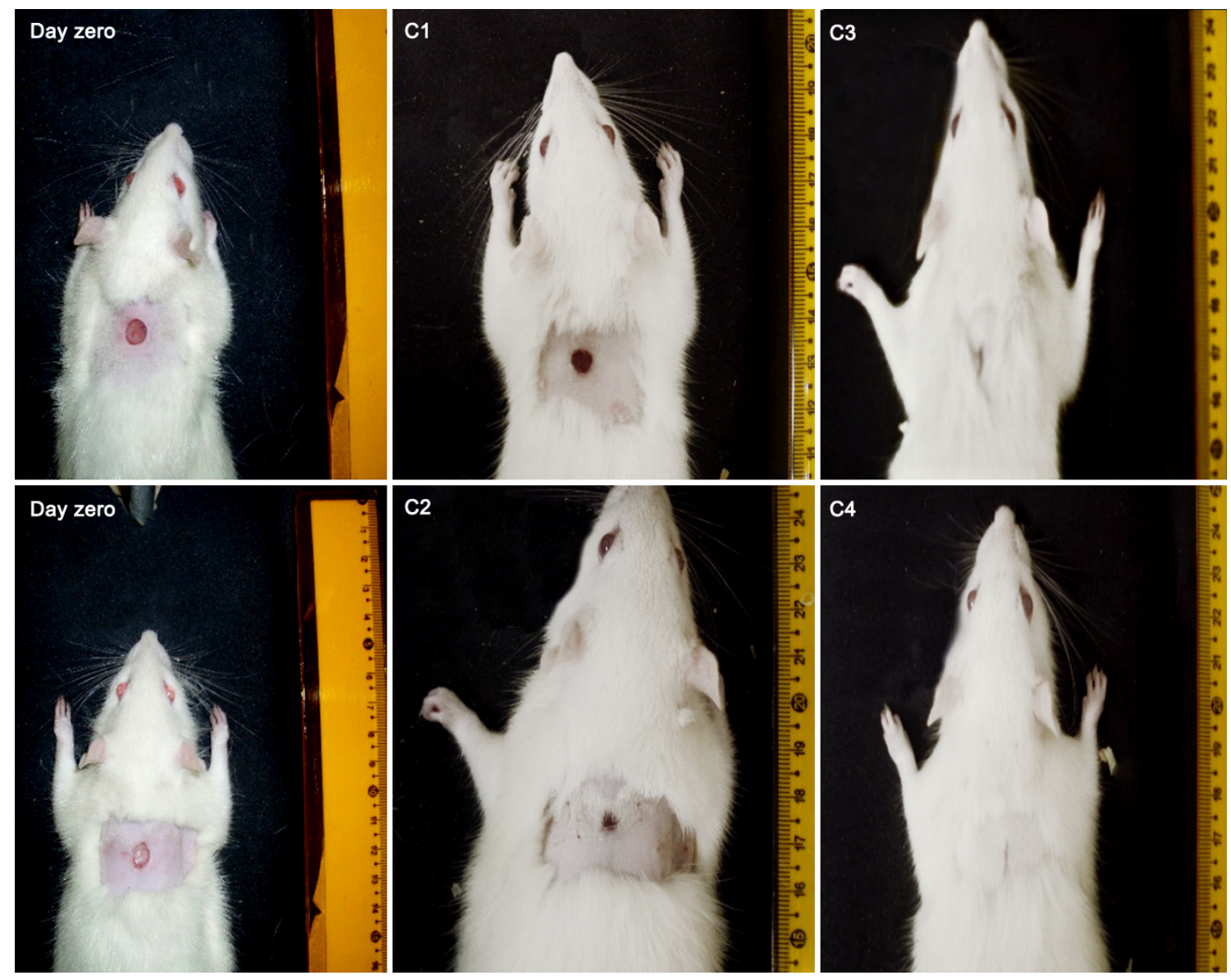

Figure 2 - Macroscopic depiction of the wounds in rat dermis. Control groups treated with distilled water on day 0 , day $7(\mathrm{C} 1)$ and day $14(\mathrm{C} 3)$. Groups treated with L. pacari extract at $10 \%$ on day $0,7^{\text {th }}$ day $(\mathrm{C} 2)$ and $14^{\text {th }}$ day $(\mathrm{C} 4)$.

We remember that healing is a dynamic and gradual process, composed of the following phases: coagulation, inflammation, proliferation, wound contraction and remodeling (Mandelbaum et al. 2003). Coagulation is the immediate onset phase which leads to the release of vasoactive substances and triggering of the coagulation cascade. In the inflammatory phase, in addition to releasing chemical mediators (lymphocytes, macrophages), fibronectin synthesis is also

Table 1 - Medians of histologic variables evaluated at the $7^{\text {th }}$ day in the treated groups (L. pacari extract at 10\% (w/v) and control group). Mann-Whitney test, and Dunn post-test $* p<0.05$.

\begin{tabular}{lccc}
\hline Histologic variables & $\begin{array}{c}\text { Control } \\
\text { (distilled water) }\end{array}$ & $\begin{array}{c}\text { L. pacari extract } \\
\mathbf{( 1 0 \% )}\end{array}$ & $\boldsymbol{p}$ \\
\hline Blood vessels & 1.0 & 2.5 & $0.007^{*}$ \\
Fibrin & 1.0 & 1.0 & 0.67 \\
Hyperemia & 1.0 & 1.0 & 0.44 \\
Hemorrhage & 1.0 & 1.0 & 0.67 \\
Inflammatory infiltrate (PMN cells) & 1.0 & 1.0 & 0.67 \\
Collagen & 1.0 & 2.0 & $0.0083^{*}$ \\
\hline
\end{tabular}



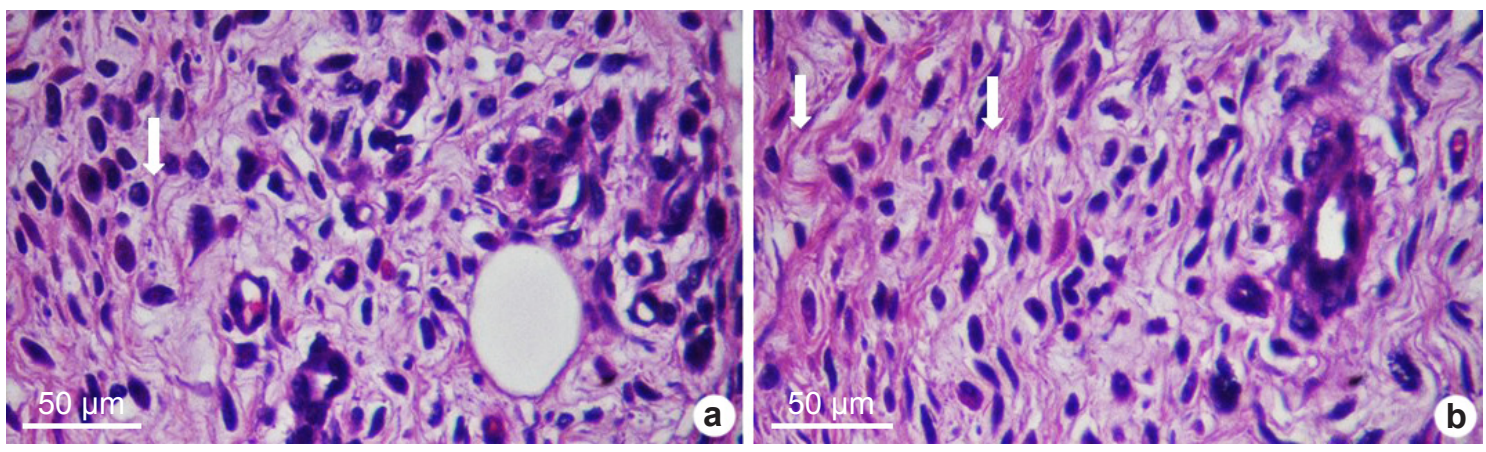

Figure 3 - a-b. Photomicrography of tissue fragments from rat dermis, stained with hematoxylin and eosin after 7 days of treatment. Collagen content (arrows) therein highlighted - a. group treated with distilled water (control); $b$. group treated with $10 \%$ L. pacari extract. Mann-Whitney test, Dunn post-test. * $\mathrm{p}<0.05$.

started. In the proliferation phase, re-epithelization and hyperplasia of the endothelium, fibroplasia for the formation of granulation tissue (with fibronectin, glycosaminoglycans and collagen) and angiogenesis, which leads to greater nutrient supply and tissue oxygenation. The contraction of the wound coincides with the stage of proliferation. The last phase is the long-term remodeling, constituted by extracellular matrix production, wound closure, maturation of the scar tissue and cure (Hardwicke et al. 2008).

In the literature, there is a recent article on wound healing with the use of $L$. pacari leaves (Pereira et al. 2018), that is carried out more deeply than ours, demonstrating this activity in in vivo and in vitro models. The authors showed that the wound healing activity of $L$. pacari is seemingly multi-target and involves the inhibition of the proliferative and anti-inflammatory phases, reactive oxygen species scavenging and positive modulation of the remodeling phase. We emphasize that our data corroborate theirs, in the sense of having found some similar results related to an increase in the rate of wound contraction through reepithelialization and also regarding some histological variables such as increased collagen content and number of blood vessels, fibrin and presence of inflammatory infiltrates. However, what we want to highlight most is that we use cultivated species and not collected from the natural environment (as Pereira et al. 2018) and this is the main difference between both studies. Our data allow to suggest that we were able to cultivate the species in order to maintain wound healing activity and we were also able to maintain the biosynthesis of punicalagin, one of the polyphenols also detected by Pereira et al. (2018) and that it was related to play a role in the
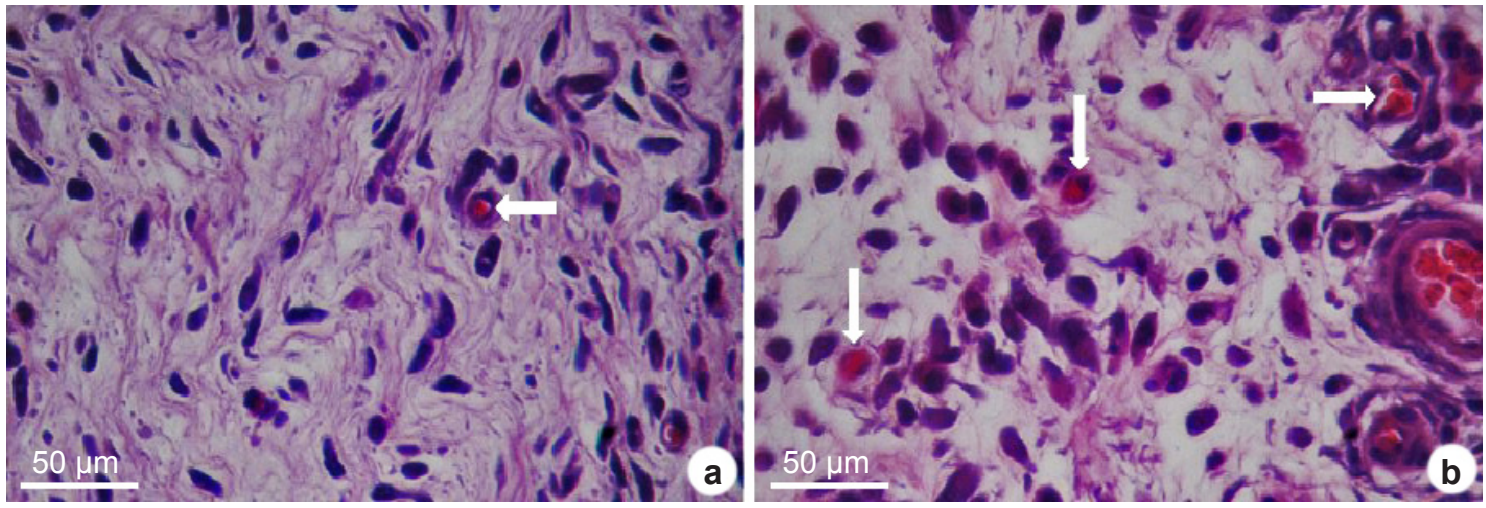

Figure $4-a-b$. Photomicrography of tissue fragments from rat dermis, stained with hematoxylin and eosin after 7 days of treatment. Blood vessels (arrows) therein highlighted - a. group treated with distilled water (control); b. group treated with $10 \%$ L. pacari extract. Mann-Whitney test, Dunn post-test. * p $<0.05$. 
reported biological effects. These findings are very important because it opens perspectives on the sustainability of the species. We would like to remember that when proposing the cultivation of a medicinal species, one must consider the content of secondary metabolites, which is affected by environmental, genetic and agronomic factors (Sampaio et al. 2011). Thus, it can be said that this work of Pereira et al. (2018) was a tool to monitor the biological activity in relation to the proposed cultivation of $L$. pacari.

Literature states that tannins aid wound healing process as well as accelerate burn healing, hence their capacity to form complexes with proteins, which leads to the formation of a protective layer over wound area, thence allowing the epidermis restructuration (Mello \& Santos 2017).

Comparing our findings to that of other tannin-rich plants, similar data are verified as described for Tabernaemontana catharinensis extract which presented a healing effect on rat cutaneous wounds with an increase in the number of blood vessels and fibroblasts, while also promoting decrease in wound area (Janning et al. 2011). The hydroalcoholic extract of Schinus terebinthifolius delayed the re-epithelization of the wounds in rats, thence presenting a larger wound area than the control group, as well as larger number of mononuclear cells (Castelo Branco et al. 2006). The use of Stryphnodendron obovatum and Stryphnodendron polyphyllum did not lead to a significant difference in the healing of cutaneous wounds of rats, but ethyl acetate fraction of S. polyphyllum (36.16\% of tannins) lead to a decreased wound area after 7 days (Lopes et al. 2005). Coelho et al. (2010) demonstrated that ointment with 10\% Stryphnodendron adstringens extract favored the healing process of cutaneous wounds in rats. Hayouni et al. (2011) found that an ointment with $5 \%$ methanolic extract of Punica granatum (rich in punicalagin) significantly increased the contraction of the wound, decreased the period of epithelization, increased the levels of collagen, fibrin and hydroxyproline and on the $8^{\text {th }}$ day presented a wound healing of $83.5 \%$. Histological analysis demonstrated the well-formed epidermis, with the presence of hair follicles and absence of inflammatory infiltrate. Ismail et al. (2012) showed that $P$. granatum fruit peels leads to an improvement in epithelialization, resistance to rupture, greater contraction of wounds and increase in hydroxyproline production.
Regarding Lythraceae wound healing properties, the ethanolic extract of the leaves of Ammannia baccifera, which contains flavonoids and tannins, induced improvement in the different phases of wound healing process, including collagen synthesis, maturation, wound contraction and epithelization (Rajasekaran et al. 2012). The extract of Lawsonia inermis L. leaves provided a reduction in the period of epithelization, high resistance to skin rupture, increase in granulation tissue, reduction of $71 \%$ in wound area, increase of collagen and fibroblasts and little inflammatory infiltrate. These benefits were attributed to the chemical compounds present in the extract, amongst them: tannins, gallic acid, mannitol and lawsone (Nayak et al. 2007). Muhammad \& Muhammad (2005) suggested that the extract of Lawsonia inermis L. leaves may be used in infected burn wounds, since it was able to inhibit the growth of microorganisms that caused pathological infection.

Finally, we highlight that the results found in the experimental conditions described corroborate to the popular use of $L$. pacari leaves in the treatment of wounds. It can also be interpreted as an incentive to expand the cultivation of this medicinal plant, aiming at the sustainability of the plant species and their domestication for therapeutic use.

\section{Acknowledgements}

Authors thank CAPES and CNPq (Processo $\left.\mathrm{n}^{\mathrm{o}} 564599 / 2010-7\right)$ for financial support.

\section{References}

Asres K, Bucar F, Knauder E, Yardley V, Kendrick H \& Croft SL (2001) In vitro antiprotozoal activity of extract and compounds from the stem bark of Combretum molle. Phytotherpy Research 15: 613617.

Biondo-Simões MLP, Alcantara EM, Dallagnol JC, Yoshizumi KO, Torres LFB \& Borsato KS (2006) Cicatrização de feridas: estudos comparativo em ratos hipertensos não tratados e tratados com inibidor da enzima conversora da angiotensina. Revista do Colégio Brasileiro de Cirurgiões 33: 74-78.

Brazil (2010) Farmacopeia Brasileira. Agência Nacional de Vigilância Sanitária, Brasília. 545p.

Brazil - Ministério do Meio Ambiente e Instituto Brasileiro do Meio Ambiente e dos Recursos Naturais Renováveis (2011) Monitoramento do desmatamento nos biomas brasileiros por satélite. Monitoramento do bioma Cerrado 2009-2010. Centro de Informação, Documentação Ambiental e Editoração Luís Eduardo Magalhães, Brasília. 65p. 
Brazil - Ministério do Meio Ambiente (2013) Biomas - Cerrado. Available at <http://www.mma.gov.br/ biomas/cerrado $>$. Access on 12 June 2013.

Cabral PRF \& Pasa MC (2009) Mangava-brava: Lafoensia pacari A. St. - Hil. (Lythraceae) e a etnobotânica em Cuiabá, MT. Revista Biodiversidade 8: 2-21.

Camillo J, Bara MTF, Sampaio BL \& Paula JR (2016) Lafoensia pacari. In: Vieira RV, Camillo J \& Coradin L (eds.) Espécies nativas da flora brasileira de valor econômico atual ou potencial: plantas para o futuro: Região Centro-Oeste. Ministério do Meio Ambiente, Brasília. Pp. 825-834.

Carneiro CC, Santos SC, Lino Junior RS, Bara MTF, Chaibub BA, Reis PRM, Chaves DA, Silva AJR, Silva LS, Silva DM \& Chen-Chen L (2016) Chemopreventive effect and angiogenic activity of punicalagin isolated from leaves of Lafoensia pacari A. St.-Hil. Toxicology and Applied Pharmacology 310: 1-8.

Carvalho PER (2003) Espécies Arbóreas Brasileiras. Embrapa Informação Tecnológica, ColomboParaná. 1039p.

Castelo Branco ML, Ribas JM, Malafaia O, Oliveira MA, Czeczko NG, Aoki S, Cunha R, Fonseca VR, Teixeira HM \& Aguiar LRF (2006) Avaliação do extrato hidroalcoólico de Aroeira (Schinus terebinthifolius Raddi) no processo de cicatrização de feridas em pele de ratos. Acta Cirúrgica Brasileira 21: 17-22.

Coelho JM, Antoniolli AB, Silva DN, Carvalho TMMB, Pontes ERJC \& Odashiro NA (2010) O efeito da sulfadiazina de prata, extrato de ipê-roxo e extrato de barbatimão na cicatrização de feridas cutâneas em ratos. Revista do Colégio Brasileiro de Cirurgiões 37: 45-51.

Dias JE \& Laureano LC (2009) Farmacopeia Popular do Cerrado. Articulação Pacari (Associação Pacari), Goiás. 352p.

Doig JA, Dudley H, Williams PB \& Oelrichs LB (1990) Isolation and structure elucidation of punicalagin, a toxic hydrolysable tannin, from Terminalia oblongata. Journal of the Chemical Society Perkin Transactions 1: 2317-2321.

Fachim E \& Guarim VLMS (1995) Conservação da biodiversidade: espécies da flora de Mato Grosso. Acta Botanica Brasilica 9: 281-302.

Garros DC, Campos ACL, Tâmbara EM, Tenório SB, Torres OJM, Agulham MA, Araújo ACF, SantisIsolan PMB, Oliveira RM \& Arruda ECM (2006) Extract from Passiflora edulis on the healing of open woundsin rats: morphometric and histological study. Acta Cirurgica Brasileira 21: 55-65.

Hardwicke J, Schmaljohann D, Boyce D \& Thomas D (2008) Epidermal growth factor therapy and wound healing - past, present and future perspectives. Surgeon 6: 172-177.

Hayouni EA, Miled K, Boubaker S, Bellasfar Z, Abedrabba M, Iwaski H, Oku H, Matsui T, Limam F \& Hamdi M (2011) Hydroalcoholic extract based-ointment from
Punica granatum L. peels with enhanced in vivo healing potential on dermal wounds. Phytomedicine 18: 976-984.

Ismail T, Sestili P \& Akhtar S (2012) Pomegranate peel and fruit extracts: a review of potential antiinflammatory and anti-infective effects. Journal of Ethnopharmacology 143: 397-405.

Janning D, Albuquerque CAC \& Barauna SC (2011) Avaliação preliminar do extrato hidroalcoólico de Tabernaemontana catharinensis no processo de cicatrização de feridas em pele de ratos (Rattus norvegicus). Revista Eletrônica de Farmácia 8: 53-64.

Jesus NZT, Lima JCS, Silva RM, Espinosa MM \& Martins DTO (2009) Levantamento etnobotânico de plantas popularmente utilizadas como antiúlceras e antiinflamatórias pela comunidade de Pirizal, Nossa Senhora do Livramento-MT, Brasil. Brazilian Journal of Pharmacognosy 19: 130-139.

Joly AB (2002) Botânica: introdução à taxonomia vegetal. $13^{\mathrm{a}}$ ed. Cia. Editora Nacional, São Paulo. 599p.

Klink CA \& Machado RB (2005) A conservação do Cerrado brasileiro. Megadiversidade 1: 147-155.

Logeeswari K \& Sripathi SK (2012) Wound healing medicinal plants: a review. International Journal of Chemical, Environmental and Pharmaceutical Research 3: 199-218.

Lopes GC, Sanches ACC, Nakamura CV, Dias BP, Hernandes L \& Mello JCP (2005) Influence of extracts of Sthyphnodendron polyphyllum Mart. and Stryphnodendron obovatum Benth. on the cicatrisation of cutaneous wounds in rats. Journal of Ethnopharmacology 99: 265-272.

Lorenzi H (1998) Árvores brasileiras: manual de identificação e cultivo de plantas arbóreas nativas do Brasil. Editora Plantarum, Nova Odessa. 352p.

Machado TB, Leal ICR, Amaral ACF, Santos KRN, Silva MG \& Kuster RM (2002) Antimicrobial ellagitannin of Punica granatum fruits. Journal of the Brazilian Chemical Society 13: 606-610.

Mandelbaum SH, Santos EP \& Mandelbaum MHS (2003) Cicatrização: conceitos atuais e recursos auxiliares. Anais Brasileiros de Dermatologia 78: 393-410.

Mello JCP \& Santos SC (2017) Taninos. In: Simões CMO, Schenkel EP, Mello JCP, Mentz LA \& Petrovick PR (orgs.) Farmacognosia: do produto natural ao medicamento. Editora Artmed, Porto Alegre. Pp. 235-248.

Monteiro JM, Albuquerque UP, Araujo EL \& Amorim ELC (2005) Taninos: uma abordagem da química à ecologia. Quimica Nova 28: 892-896.

Muhammad SH \& Muhammad S (2005) The use of Lawsonia inermis linn. (henna) in the management of burn wound infections. African Journal of Biotechnology 4: 934-937.

Nayak BS, Isitor G \& Pillai GK (2007) The evidence based wound healing activity of Lawsonia inermis Linn. Phytotherapy Research 21: 827-831. 
Okuda T, Yoshida T \& Hatano T (1989) New methods of analyzing tannins. Journal of Natural Products 52: $1-31$.

Oliveira ST, Leme MC, Pippi NL, Raiser AG \& Manfron MP (2000) Formulações do confrei (Symphytum officinalis L.) na cicatrizacão de feridas cutâneas em ratos. Revista da Faculdade de Zootecnia, Veterinária e Agronomia 7: 61-65.

Pereira LOM, Vilegas W, Tangerina MMP, Arunachalam $\mathrm{K}$, Balogun SO, Orlandi-Mattos PE, Colodel EM \& Martins DTD (2018) Lafoensia pacari A. St.-Hil.: Wound healing activity and mechanism of action of standardized hydroethanolic leaves extract. Journal of Ethnopharmacology 219: 337- 350.

Rajasekaran A, Sivakumar V \& Darlinquine S (2012) Evaluation of wound healing activity of Ammannia baccifera and Blepharis maderaspatensis leaf extracts on rats. Brazilian Journal of Pharmacognosy 22: 418-427.

Ribeiro JF \& Dias T (2007) Fatores bióticos, vegetação e flora. In: Arns KY \& Alves M (orgs.) Biodiversidade do Cerrado e Pantanal: áreas e ações prioritárias para conservação da biodiversidade. $2^{\mathrm{a}}$ ed. Ministério do Meio Ambiente, Brasília. Pp. 21-138.

Romani A, Campo M \& Pinelli P (2012) HPLC/DAD/ ESI-MS analyses and anti-radical activity of hydrolyzable tannins from different vegetal species. Food Chemistry 130: 214-221.

Sampaio BL, Bara MTF, Ferri PH, Santos SC \& Paula JR (2011) Influence of environmental factors on the concentration of phenolic compounds in leaves of Lafoensia pacari. Brazilian Journal of Pharmacognosy 21: 1127-1137.

Santos LW, Coelho MFB \& Pirani FR (2009) Fenologia de Lafoensia pacari A.St.-Hil. (Lythraceae) em Barra do Garças, Mato Grosso, Brasil. Revista Brasileira de Plantas Medicinais 11: 12-17.

Santos DYAC, Salatino MLF \& Salatino A (2000) Foliar flavonoids of Lafoensia (Lythraceae). Biochemical Systematics and Ecology 28: 487- 488.

Santos MA, Barbieri A, Carvalho JAM \& Machado CJ (2010) O Cerrado brasileiro: notas para estudo. Cedeplar, Belo Horizonte. 15p.

Sano SM, Almeida SP \& Ribeiro JF (2008) Cerrado: ecologia e flora. Embrapa Informação Tecnológica, Brasília. 1279p.

Souza LF (2007) Recursos vegetais usados na medicina tradicional do Cerrado (comunidade de Baús, Acorizal, MT, Brasil). Revista Brasileira de Plantas Medicinais 9: 44-54.

Vila Verde GM, Paula JR \& Carneiro DM (2003) Levantamento etnobotânico das plantas medicinais do cerrado utilizadas pela população de Mossâmedes (GO). Brazilian Journal of Pharmacognosy 13: 64-66.

Yoshida T, Amakura Y \& Yoshimura M (2010) Structural features and biological properties of ellagitannins in some plant families of the order myrtales. International Journal of Molecular Sciences 11: 79-106. 